\title{
STUDY OF THE QUALITY OF SERVICES ON THE EXAMPLE OF THE SELECTED CHAIN OF DISCOUNT STORES
}

\author{
ANNA E. WOLNOWSKA \\ Maritime University of Szczecin, POLAND \\ e-mail: a.wolnowska@am.szczecin.pl
}

RECEIVED

ACCEPTED

JEL

CLASSIFICATION

KEYWORDS

ABSTRACT
16 August 2017

15 December 2017

$E 23, I 23, \mathrm{~J} 8$

service quality, Servqual, customer satisfaction, discount store

The share of discount stores in the Polish retail trade, has had a strong trend upward for several years. Poles pay more and more attention to the quality of the services offered by the discount stores network. Hence the aim of the article is testing the quality of services in the selected network.

The research was conducted in years 2015-2017 on the basis of the case study using Servqual method. The use of this method allowed to determine customer satisfaction in Netto discount stores chain as the difference between customer perception and expectations. The five criteria: tangibles, reliability, responsiveness, assurance, empathy were taken into account for estimating the quality of services. The conducted research allowed to state which of the mentioned areas is on a satisfactory quality level and which one is not, what weaknesses and strengths of the service offered by the studied discount stores chain are and what the relation between customer satisfaction and service quality is. The analysis of research results allows to state that retail chains should examine the quality level of their services systematically in order to be able to conduct expansive policy on Polish market regarding the growth of customer requirements.

\section{Introduction}

The subject of the research was the Netto shops chain located in Szczecin, West Pomeranian Voivodeship. The company possesses more than 360 shops in Poland, of which approximately $6 \%$ is located just in Szczecin. Moreover, this company possesses three distributive warehouses for its disposal and employs more than 5 thousand 
persons. Such a state of possession gives the Danish retailer the third position in the Polish discount store market. (www.wiadomoscihandlowe.pl, 2017).

Discount stores are the shops that sell the standard articles at the discounted prices, accepting the lower profit margins and selling more products in this way. The assortment they have to their disposal is narrowed down to between 1,000 and 2,000 basic products (sjp.pl, 2017). The discounts often provide the lower prices themselves by creating their own brands, minimised supply chains and the faster rotation of goods (dobryslownik.pl, 2017).

In 2016, the dynamics of the increase in the number of all discount stores in Poland, was $2.1 \%$. This is slightly more than in $2015-2.8 \%$ but much less than in the previous years. in 2010 , the number of the discounts in Poland increased by $12.1 \%$, in $2011-12.8 \%$, in $2012-13.2 \%$. From 2013 the increase of the number of discounts in Poland was not so intensive $-12.8 \%$, in $2012-13.2 \%$. From 2013 the increase of the number of discounts was not as intensive as it used to be $-11.7 \%$, in $2014-9 \%$. In this issue the discount stores of the Biedronka chain are the front runner - their percentage among in Poland is higher than $70 \%$ (www.portalspozywczy.pl, 2017).

Pursuant to the above data it may be assessed that the owners of the discount store chains are still fighting for the market against hypermarkets and other forms of the trade.

Because of this reason, the discount stores have started to put a bigger impact on the quality of the services provided by introducing a more attractive interior design, new services for customers and opened new divisions and subsidiaries in the suburbs.

The aim of the research was to analyse the quality of services provided by the Netto discounts on the basis of the case study by means of the Servqual method and demonstration that the area customer satisfaction rating reflects the quality of services provided in more clear way and allows to improve them successively.

\section{Litepature review}

The survey of the quality of services is a complex process (Bukowska-Piestrzyńska, 2017) and, according to A. Jonas, it should be considered from three perspectives: customer, company marketing concept and competition (Czubała, Jonas, Smoleń, Wiktor, 2006). As it is specified by K.M. Staszyńska (1998) in such cases two phases should be also extracted: explorative and diagnostic.

The mentioned principles and phases may be found in the most of methods that serve to research the quality of services (Malati, Maheshwari, Jain, 2012). The methods used the most often are: Mystery shopping, Servqual, Servperv, Critical Incident Technique (CIT), Customer Satisfaction Index (CSI), Servsess (Landrum, Prybutok, Kappelman, Zhang, 2008).

The choice of methods depends on the needs and type of the activities conducted by a given company, the sector and know-how and abilities of the persons, who arrange the research of customer satisfaction.

Mystery Shopping is a process to measure the quality with feedback, it comes true the best in the services - in their part related to the direct interactions of personnel with consumer.

This method allows to execute the research in a continuous method, but is quite laborious, as it requires to prepare a precise questionnaire so as to use it to register facts not the subjective researcher's assessments. The choice of a mysterious customer is not incidental, but strongly connected with the research area. It should remind a typical customer using the service that is assessed (Dziadkowiec, 2004).

The Servqual method was developed at the end of eighties by a team of American scientists: A. Parasuraman, V.A. Zeithalm and L.L. Berry (1991) and was used initially to measure the banking services. Currently it is used 
to the issues of the qualitative processes connected with external and internal customers, i.e. to the production processes of not only services but products too. It consists in the measurement of differences that are present between the quality perceived by customer and the quality expected by this customer. This is one of the most popular quality meters (Roslana, Wahabb, Abdullahc, 2015). To determine the mentioned difference, this is to research simultaneously the customer expectations concerning a given service and its implementation in case of a specific subject. In the Servqual method it is necessary to research five the most important dimensions of service (Qadri, 2015) that are evaluated and compared mutually (Wolnowska, 2009a). Using such a basis, a given company is able to determine its level of implementation of service towards customer and also acquire the more precise information related to the sources of problems related to the quality of service processes (Orel, Kara, 2014). The following may be included to the dimensions mentioned above:

- tangibles - appearance of physical facilities, equipment, personnel, communication materials,

- reliability - ability to provide in agreed time limit and of the adequate quality,

- responsiveness - quick reaction on current customer requirements,

- assurance - know-how and good manners of personnel and ability to inspire trust and confidence of customers,

- empathy - personalised and caring attention assured by the company to customers, identification with customers' needs.

To evaluate the service quality level in the scope of each of mentioned dimensions are to be designed two questionnaires, each consisting of 22 questions that relate to customers' expectations and the same questions related to way to perceive the service related to the company the service of which a respondent uses.

Each question is related to one of five Servqual areas. In the Servqual method, the seven point Likert's scale is used. It allows to assign the particular statements the value from I agree entirely to I disagree entirely. The bigger is the difference between the expected and perceived values, the bigger is purchaser's dissatisfaction. And if the difference is zero or the quality perceived is higher than the expected, then we may recognise a given element as fulfilling customer's expectations or even exceeding these expectations.

Also the third questionnaire is used in the method. This third questionnaire is related to the importance of the particular quality dimensions. It is made by the method of the constant sum used. Customer receives 100 points that he/she should distribute among the dimensions. There are present various interpretations of customer's expectations, which, of course, make the measurements much more complicated (Charles, Kumar, 2014). They may be interpreted as the service expected, as the perfect pattern or as the essential variable. Servqual is based on the gap between expectations and service execution, not on the service validity and execution (Wolnowska, 2009b). Trying to solve the problem related to expectations, in 1994 Parasuraman, Zeithaml and Berry divided expectations into two areas: the first to measure the services desirable, the second on the other hand to measure what services constitute a minimum to accept (Parasuraman et al., 1994). However, in 2000 Caruana, Ewing and Ramaseshan questioned the usefulness of measuring of different levels of expectations, claiming that the minimum expectations do not bring much value do not bring much value to quality service measurement, but to the contrary, cause additional problems in the interpretation of expectations (Caruana, Ewing, Ramaseshan, 2000).

The next known method of the research of the customer's satisfaction, in the form of a questionnaire interview, is CIT. In this method, there are taken into consideration the events, so called critical events related to customer's 
satisfaction or extreme dissatisfaction. The critical events are as the elements that contribute in a significant way or reduce the result of the action taken (Wolnowska, Komorowska, Wardal, 2010).

Simpler in relation to Servqual is the Servperv method (Kucińska, Kołosowski, 2009). In this method, the customers' expectations are not taken into consideration but only their subjective evaluation of their observations. The quality of services $Q$ is equated to the customer's perception $P$. The basis for assessment is five dimensions:

- perception of the key products features,

- reliability,

- reaction to customer's needs,

- confidence in implementation,

- company's consolidation with customer.

As in the case of the Servqual method, the respondents speak out on the subject of the validity of particular dimensions by distributing 100 points among them in the form of the questionnaire. The criteria are evaluated in the seven point Likert scale. The number of the criteria of evaluation taken into consideration in this method may be bigger than in the Servqual method (Trinh Thuy Anh, Phan Minh Tai, 2013).

The Customer Indication Index (CSI) is also treated as a tool to measure the effectiveness of marketing activities and allow to measure the level of customer satisfaction in relation to previously determined categories approved by the purchasers as the most important (Witkowska, 2007).

Mentioned methods, are also used as the questionnaire methods for customer satisfaction research. The full description of the customer's satisfaction are described by R.B. Woodruff and S.F. Gardial who determine that this is a positive or negative customer's feel in relation to the value received as a result of use the determined product offer in the specific situation (Woodruff, Gardial, 1996). This feel may also have a character of the direct reaction or a series of experiences in the determined frequency. The satisfaction level depends, among others on the level of wealth, experience, age and personality (Dziekoński, 2004).The relation between the quality of services and satisfaction was aptly captured by M.J. Bittner and A.R. Hubbert. They took into consideration that the quality of services includes the overall impression on the service provider and the services provided by this provider, whilst the satisfaction mat refer to one event only. Pursuant to them, the quality of services provided is a broader concept and includes satisfaction as a transitional phenomenon (Bitner, Hubbert, 1994).

Summing up the above considerations, it may be concluded that despite differences between the quality of services and satisfaction of them they are closely connected one with another. That is why in the first and second cases the above mentioned methods may be used.

\section{Method}

The research was executed between 2015-2017 basing on the case study by means of the Servqual method. The following research order was accepted:

- development of questionnaire surveys,

- selection of the test sample,

- execution of questionnaire research,

- calculation of the Servqual values for particular areas,

- calculation of the unqualified Servqual value,

- calculation of the weighted Servqual value, 
- determination of the standard deviation for the weighted Servqual value,

- analysis of results.

\section{Results}

The research was executed on the group of 340 respondents in the direct way with $100 \%$ return rate. The respondents were divided into two groups, which is shown on Figure 1. It may be noted that the largest group of Netto company customers is included within the age of 18-30 years old customers and a little less within the age $45-60$ and $30-45$ years old.

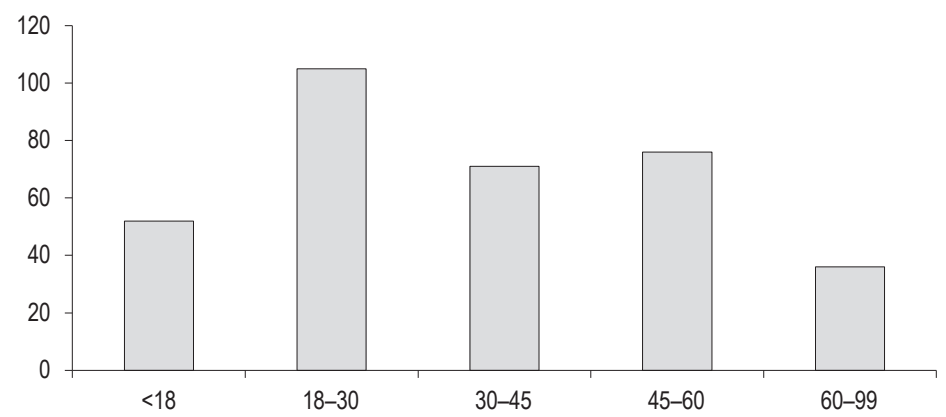

Figure 1. Respondents' age

Source: own elaboration.

The respondents made their purchases in the chosen discount network with the determined frequency shown on Figure 2. The research results manifest that the respondents made their purchases the most often every two weeks what may manifest they treated discounts equally to hypermarkets. Therefore, this is the information that the respondents perform in those places the purchases of the bigger volume, so called weekly.

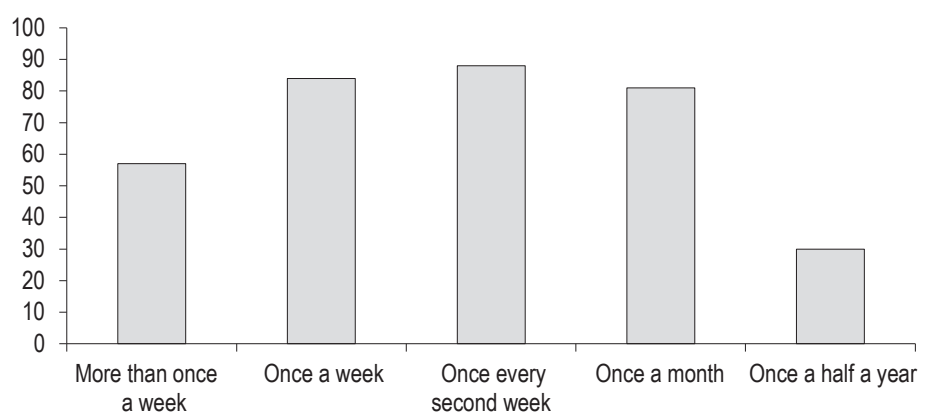

Figure 2. The frequency of purchases executed

Source: own elaboration. 
The respondents determined the validity of particular areas, dividing 100 points among them. This is shown on Figure 3. The most important dimension for respondents is reliability, whilst the less important area is the empathy.

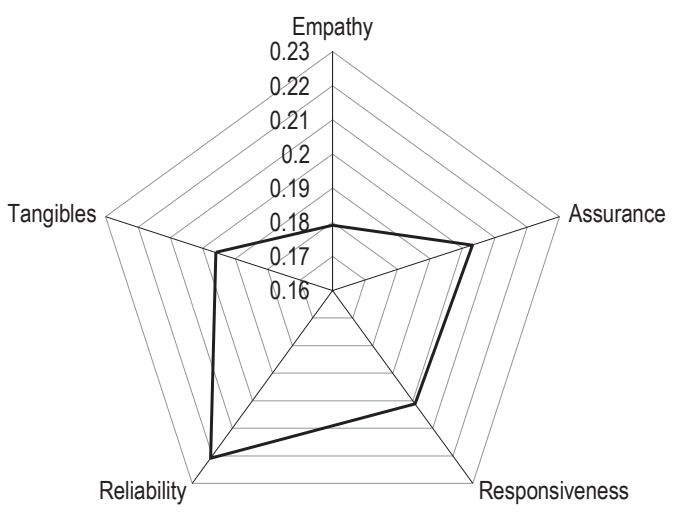

Figure 3. The values of particular qualitative features of particular quality features of the researched services Source: own elaboration.

The respondents' answers demonstrated the existence of a considerable gap between expectations and perception of the services provided. The biggest discrepancy was noted in the question 11 concerning the reaction speed of the company to customers' needs and the question 12 concerning remunerate customers for service delays. The least gap was noted in the area of the material providing the service, concerning the transparency, timeliness and reliability of promotional newsletters. The gap values to the particular questions are shown on Figure 4.

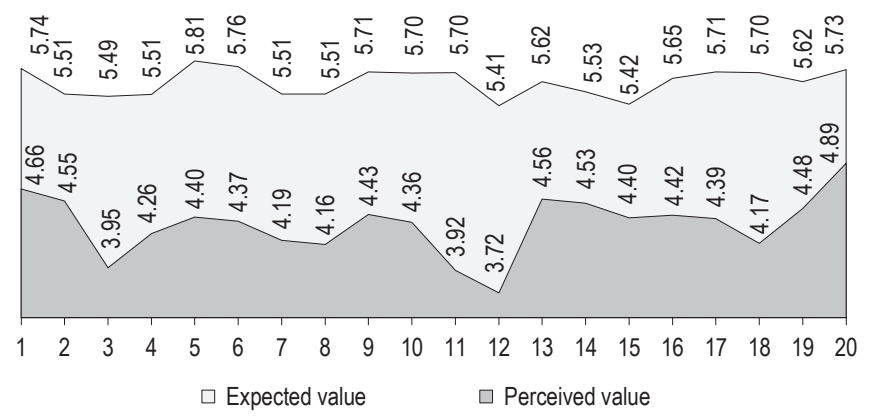

Figure 4. Comparison of expectations and perception of the Netto discount chain customers

Source: own elaboration. 
The Servqual weighted and non-weighted result was determined on the basis of the data collected, in which there were taken into consideration the evaluations of particular dimensions by respondents. The research results are shown on Figure 5.

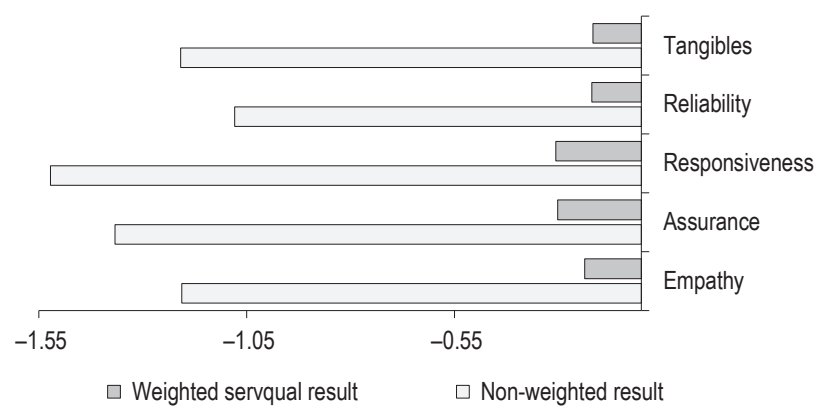

Figure 5. Weighted and non-weighted Servqual result

Source: own elaboration.

The evaluation of the importance of individual dimensions did not produce surprising results. However, it is an indication to the Netto company, which of the researched areas are particularly important to the discount customers and nec essary to develop. Such information may also suggest the discount's strategic activities, spreaded over a specified time period.

It was determined on the basis the collected results and calculations of the weighted Servqual value, the standard deviation was determined for the each of dimensions that is shown on Figure 6 . The most differentiated population refers to the areas: tangibles -0.052 , empathy -0.05 and responsiveness -0.049 . The respondents gave the extreme answers in these areas. There is the opposite situation in the case of the assurance and reliability criteria. Here, the respondents' answers were not so varied and deviated one from another.

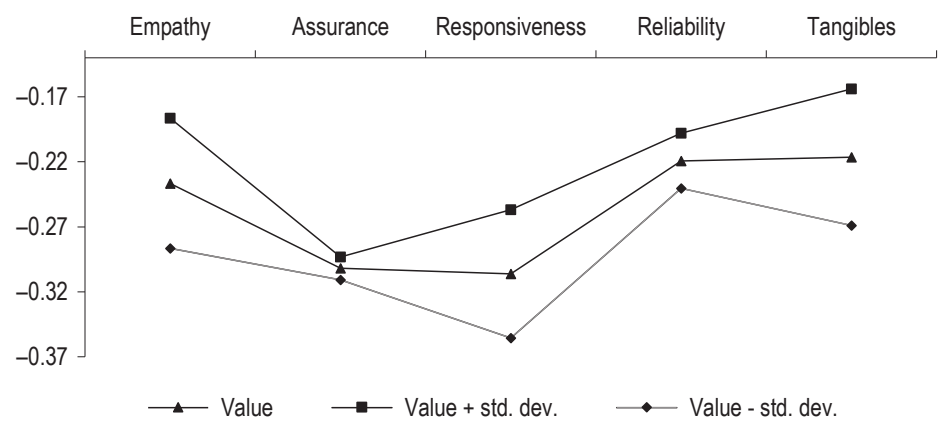

Figure 6. Comparison of the weighted Servqual result with the standard deviation taken or not into consideration Source: own elaboration. 


\section{Limitations}

The survey was conducted among Netto discounts in Western Pomerania, so the test results may or may not necessarily represent the views of Netto discounts throughout the country.

\section{Conclusions}

Customer's satisfaction cannot be omitted in the quality service research. It should be used these methods that take the customer's needs and expectations into consideration. And, although we may use the Servperv method in improving the service quality, assuming the customers' expectations on the highest level, however, the Servqual method is more advantageous to the research customers' needs in a detailed way. This method allows to:

- determine the quality service level related to each of five basic dimensions,

- calculation of the weighted quality level,

- determination of the average level of discrepancy between the expectations

- of respondents and their perception of the service provided with the area validity taken into consideration,

- identification of customers' expectations and experience and monitoring

- these changes in time,

- comparison of received research results with other, competitive companies

- of the sector,

- tracing the strengths and weaknesses the services offered by a company,

- determination of the level of service provided by one organisational units for the benefit of others within one company.

The quality measurement methods have the operational value only when in their result we are able to determine the areas or places in which the service fulfilled or not fulfilled the customer's expectations.

In the future, the analysis might be extended by determination of customers' preferences concerning the validity of particular areas taking into consideration the age groups and frequency of purchases in the researched discount chain. The result of such an analysis could serve a given trade company to formulate the marketing and strategic activities.

\section{Acknowledgments}

This article is a result of the research implemented in the Transport Engineering Institute of the Faculty of Economics and Transport Engineering of the Maritime University of Szczecin and was made within the statutory cooperation 5/S/IIT/17 on: Forming the quality in service and product manufacturing economic systems. The proposals for methodology and implementation.

\section{References}

Bitner, M.J., Hubbert, A.R. (1994). Ecounter satisfaction versus overall satisfaction versus quality. London: Sage Publications Inc. Bukowska-Piestrzyńska, A. (2017). Jakość usług zdrowotnych na przykładzie usług stomatologicznych. Problemy Jakości, 6, 8-16.

Caruana, A., Ewing, M., Ramaseshan, B. (2000). Assessment of the three-columb format Servqual an experimental approval. Journal of Business Research, 49 (1), 57-65.

Charles, V., Kumar, M. (2014). Satisficing data envelopment analysis: An application to SERVQUAL efficiency. Measurement, 51, 71-80.

Czubała, A., Jonas, A., Smoleń, T., Wiktor, J. (2006). Marketing usług. Kraków: Wolters Kluwer. 
Dziadkowiec, J. (2004). Mystery Schopping - metoda doskonalenia i oceny jakości usług. Problemy Jakości, 10, $24-27$.

Dziekoński, M. (2004). Lojalność wpisana w strategię. Marketing w Praktyce, 5, 18-21.

https://dobryslownik.pl/slowo/dyskont/115695/1/63869 (28.08.2017).

https://sjp.pl/dyskont (28.08.2017).

Kucińska, A., Kołosowski, M. (2009). Zastosowanie metody Serperv do oceny zadowolenia klienta. In: R. Knosala (ed.), Komputerowo zintegrowane zarządzanie (pp. 91-98). Opole: Oficyna Wydawnicza Polskiego Towarzystwa Zarządzania Produkcja.

Landrum, H., Prybutok, V., Kappelman, L., Zhang, X. (2008). Servcess: a parsimonious instrument to measure service quality and information system success. Quality Management Journal, 3, 17-25.

Malati, N., Maheshwari, R., Rahul Jain, R. (2012). A Study on Service Quality of Retail Outlets-Reliance Fresh and More using SERVQUAL Model. IMS Manthan, VII (1), 59-71.

Orel, F.D, Kara, A. (2014). Supermarket self-checkout service quality, customer satisfaction, and loyalty: Empirical evidence from an emerging market. Journal of Retailingand Consumer Services, 21, 118-129.

Parasuraman, A., Berry, L.L., Zeithalm, V.A. (1991). Refinement and reassessment of the SERVQUAL scale. Journal of Retailing, 67 (4), 420-450.

Parasuraman, A., Zeithaml, V.A., Berry, L. (1994). Reassessment of expectation as a comparison in measuring service quality. Implications for futher research. Journal of Marketing, 1 (58), 111-124.

Qadri, U.A. (2015). Measuring Service Quality Expectation and Perception Using SERVQUAL: A Gap Analysis. Business and Economics Journal, 6, 162. DOI: 10.4172/2151-6219.1000162.

Roslana, N.A.A., Wahabb, E., Abdullahc, N.H. (2015). Service quality: A case study of logistics sector in Iskandar Malaysia using SERVQUAL model. Procedia - Social and Behavioral Sciences, 172, 457-462.

Staszyńska, K.M. (1998). Customer satisfaction Problemy i metody pomiaru. Marketing Serwis, 3, 3-7.

Trinh Thuy Anh, Phan Minh Tai (2013). Enhancing customer satisfaction i terms of service quality in supermarket - the case study of Big C Supermarket in HCMC. Journal of Science Ho Chi Minch city Open University, 2 (7), 67-78.

Witkowska, J. (2007). Metoda Servqual w badaniach satysfakcji klientów usług ubezpieczeniowych. Problemy Jakości, 10, 33-38.

Wolnowska, A. (2009a). Service quality evaluation In a service and trading company with the use of servqual method. In: I.B. Arefiev, K. Chwesiuk (eds.) Analiza i prognozowanie systemów zarządzania (pp. 272-284). St. Petersburg: Północno-Zachodni Uniwersytet Techniczny.

Wolnowska, A. (2009b). Pomiar jakości usług za pomocą metody Servcess w odniesieniu do systemu informacyjnego. Ekonomika i Organizacja Przedsiębiorstwa, 7, 571-578.

Wolnowska, A., Komorowska, A., Wardal Z. (2010). Kreowanie wizerunku bibliotekarza poprzez jakość usług świadczonych w bibliotece. In: H. Brzezińska-Stec, J. Kudrawiec (eds.), Marketing wewnętrzny i zarządzanie zasobami ludzkimi w bibliotece (pp. 218-232). Białystok: Wydawnictwo Uniwersytetu w Białymstoku.

Woodruff, R.B., Gardial, S.F. (1996). Know Your Coustomer. New aproaches to Understanding Customer Value and Satisfaction. Cambridge: Backwell Publischers Inc.

www.portalspozywczy.pl (28.08.2017).

www.wiadomoscihandlowe.pl (28.08.2017).

Cite this anticle aS: Wolnowska, A.E. (2018). Study of the quality of services on the example of the selected chain of discount stores. European Journal of Service Management, 1 (25), 335-343. DOI: 10.18276/ejsm.2018.25-41. 